\title{
Contradições na avaliação de desempenho dos servidores técnico-administrativos em educação na universidade pública
}

\author{
Contradictions in the performance assessment of technical and administrative public \\ servants in education in the public university \\ Juliana de Fátima Pinto ${ }^{1}$ \\ Universidade Federal de Minas Gerais / Centro de Pós-Graduação e Pesquisas em Administração, Belo Horizonte - MG, Brasil \\ Ricardo Roberto Behr ${ }^{2}$ \\ Universidade Federal do Espírito Santo / Departamento de Administração, Vitória - ES, Brasil
}

\begin{abstract}
Resumo
O objetivo deste estudo foi compreender, a partir do entendimento dos servidores técnico-administrativos em educação e das chefias imediatas, como ocorre a avaliação de desempenho na Universidade Federal do Espírito Santo (UFES). A análise afastou-se da teoria hegemônica, permitindo uma reflexão crítica sobre como as técnicas de gestão vem sendo implementadas na administração pública. Este artigo pode ser caracterizado como uma pesquisa de abordagem qualitativa, sendo o objeto de estudo relacionado ao campo de conhecimento da administração pública. Os dados empíricos foram produzidos por meio de entrevistas semiestruturadas. Foram entrevistados 28 técnico-administrativos em educação e 11 chefias imediatas, selecionados conforme o critério da bola de neve. Utilizou-se a análise de conteúdo para o tratamento das entrevistas. Os técnico-administrativos em educação destacaram a insatisfação com a avaliação de desempenho, a importância da avaliação, o receio em avaliar a chefia imediata, a subjetividade existente na avaliação e o uso da avaliação como sistema de progressão. Para as chefias imediatas, a avaliação de desempenho é uma condição para melhoria no serviço público, existe uma dificuldade ao avaliar, há necessidade de mudanças na avaliação e, assim como os técnico-administrativos em educação, elas visualizam a avaliação como um sistema de progressão. Há insatisfação quanto à maneira como a avaliação é utilizada na universidade. Pode-se concluir que a avaliação de desempenho é um modelo importado de forma acrítica da iniciativa privada e que não resulta em melhorias efetivas no serviço público, levando ao aumento da individualidade em detrimento da coletividade.
\end{abstract}

Palavras-chave: Avaliação de desempenho. Reforma gerencial. Administração pública.

\section{Abstract}

This study aimed to understand, from the viewpoint of technical and administrative public servants in education and their immediate supervisors, how performance assessment takes place in the Federal University of Espírito Santo (UFES). The analysis turned away from the hegemonic theory, allowing a critical reflection on how the management techniques

Artigo submetido em 25 de agosto de 2014 e aceito para publicação em 6 de fevereiro de 2015.

DOI: http://dx.doi.org/10.1590/1679-395132365

${ }^{1}$ Doutoranda em Administração pelo Centro de Pós-Graduação e Pesquisas em Administração da Universidade Federal de Minas Gerais (CEPEAD/UFMG); Mestra em Administração pelo Programa de Pós-Graduação em Administração da Universidade Federal do Espírito Santo (PPGADM/UFES). Endereço: Av. Antônio Carlos, 6627, Pampulha, CEP 31270-901, Belo Horizonte - MG, Brasil. E-mail: jufapinto@gmail.com

${ }^{2}$ Doutor em Engenharia de Produção pela Universidade Federal de Santa Catarina e Pós-Doutorado em Administração pelo CEPEAD/UFMG; Professor Associado no Departamento de Administração e PPGADM da Universidade Federal do Espírito Santo. Endereço: DADM/UFES - Universidade Federal do Espírito Santo, Avenida Fernando Ferrari, 514, Goiabeiras, CEP 29075-010, Vitória - ES, Brasil. E-mail: ricardo.behr@ufes.br 
have been deployed in public administration. This article may be characterized as a qualitative research, and the study object is related to the knowledge field of public administration. Empirical data were produced through semi-structured interviews. Selected according to the snowball criterion, 28 technical and administrative public servants in education and 11 immediate supervisors were interviewed. Content analysis was used for addressing the interviews. The technical and administrative public servants highlighted discontent with the performance assessment, the significance of assessment, the fear to assess the immediate supervisor, the subjectivity observed in the assessment, and the use of assessment as a progression system. According to the immediate supervisors, performance assessment is a condition for improving the public service, there is a difficulty to assess, there is a need for changes in the assessment, and, just as the technical and administrative public servants, they see performance assessment as a progression system. There is dissatisfaction regarding the way how assessment has been used in the university. We may conclude that performance assessment is a model uncritically imported from the private sector and it does not result in actual improvements in public service, leading to an increased individuality to the detriment of collectivity.

Keywords: Performance assessment. Management reform. Public administration.

\section{Introdução}

O foco deste estudo é compreender, a partir do entendimento dos servidores técnico-administrativos em educação das classes C, D e E e das chefias imediatas, como ocorre a avaliação de desempenho na Universidade Federal do Espírito Santo (UFES). Este artigo pode ser caracterizado como uma pesquisa de abordagem qualitativa, sendo o objeto de estudo relacionado ao campo de conhecimento da administração pública.

A avaliação de desempenho é um instrumento que se difundiu nas organizações públicas e privadas, principalmente no mundo ocidental. Implementada pela primeira vez na administração pública brasileira por Getúlio Vargas, na década de 1930 (NASCIMENTO e BERNARDIM, 2007), a avaliação de desempenho tornou-se mais recorrente a partir do Plano Diretor da Reforma do Aparelho do Estado (PDRAE), no governo Fernando Henrique Cardoso (FHC).

Em 1995, Luiz Carlos Bresser-Pereira, ministro da Administração Federal e da Reforma do Estado no primeiro mandato do governo FHC (1995-1998), apresentou o PDRAE que, entre outros objetivos, propunha que os servidores deveriam apresentar um perfil mais gerencial, enquanto os cidadãos precisariam ser tratados como clientes, obedecendo à mesma lógica das organizações privadas. Para tanto, os servidores seriam avaliados por meio de indicadores de desempenho, com a expectativa de melhorar a eficiência nos servidos prestados pela administração pública (BRASIL, 1995).

Quando o presidente Luiz Inácio Lula da Silva assumiu o poder, em 2003, algumas políticas do modelo gerencial foram seguidas (PAULA, 2005a). No que se refere às instituições federais de Ensino Superior (IFES), a Lei n. 11.091, de 12 de janeiro de 2005, trouxe a estruturação do Plano de Carreira dos Cargos Técnico-Administrativos em Educação, que vinculou o desenvolvimento do servidor na carreira à progressão por capacitação profissional e à progressão por mérito profissional.

Desse modo, este estudo foi elaborado a partir dos questionamentos e das inquietações sobre o entendimento dos servidores técnico-administrativos em educação (TAE) e das chefias imediatas sobre o atual sistema de avaliação da UFES, levando em consideração as bases normativas estabelecidas para as IFES após a publicação da Lei n. 11.091/2005.

Como embasamento teórico, optou-se por uma perspectiva crítica, em especial no que concerne à política de gestão de pessoas nas organizações a partir dos estudos de Pagès, Bonetti, Gaulejac et al. (2008). Essa abordagem possibilitou compreender os objetivos ocultos das políticas de gestão de pessoas e fazer uma reflexão sobre as contradições da avaliação de desempenho utilizada no âmbito da universidade. 


\section{O Modelo Gerencial}

A diferenciação entre a gestão empresarial e a pública esteve presente nos debates acadêmicos e governamentais em vários momentos do século passado. A partir da década de 1970, países como os Estados Unidos e o Reino Unido tentaram implementar no setor público técnicas gerenciais utilizadas no setor privado (PAULA, 2005b). Nesses países, o enfoque gerencial da administração pública surgiu após Margareth Thatcher e Ronald Reagan assumirem o poder na Grã-Bretanha e nos Estados Unidos, respectivamente (BRESSER-PEREIRA, 1999).

Para Paula (2005b), a nova administração pública defendida pelo governo britânico apresentava as seguintes características: separação das atividades de execução e planejamento do governo por meio da descentralização do aparelho de Estado; privatização de empresas estatais; terceirização de serviços prestados pelo governo; regulação de atividades públicas dirigidas pelo setor privado e adoção de ideias e ferramentas gerenciais usualmente utilizadas no setor privado.

No Brasil, o governo copiou alguns modelos em busca da eficiência na máquina pública, influenciado principalmente pelas alterações estruturais que ocorriam nos países desenvolvidos. Em 1995, no governo FHC, o então Ministro da Administração Federal e Reforma do Estado, Luiz Carlos Bresser-Pereira, lançou o PDRAE. Foi a partir desse plano que as organizações públicas buscaram a modernização e a desburocratização, por meio de práticas gerenciais (SANTOS FILHO, SALLES, PRADO JÚNIOR et al., 2010).

O modelo gerencialista buscava elevar de forma contínua a produtividade econômica para atingir o processo social, implantar uma tecnologia avançada e também adotar um gerenciamento voltado ao planejamento (PAULA, 2005b). Vários aspectos da burocracia passaram, então, a ser questionados.

O paradigma gerencial contemporâneo, fundamentado nos princípios da confiança e da descentralização da decisão, exige formas flexíveis de gestão, horizontalização de estruturas, descentralização de funções, incentivos à criatividade. Contrapõe-se à ideologia do formalismo e do rigor técnico da burocracia tradicional. À avaliação sistemática, à recompensa pelo desempenho, e à capacitação permanente, que já eram características da boa administração burocrática, acrescentam-se os princípios da orientação para o cidadãocliente, do controle por resultados, e da competição administrada (BRASIL, 1995, p. 17).

Siqueira e Mendes (2009) registram que a administração gerencial preocupou-se mais com as tarefas e pouco com os servidores, precarizando o trabalho, promovendo a desmotivação e aumentando a pressão sobre o trabalhador e dificultando os diálogos e a criatividade. Já Abrucio (2007, p. 70) enfatiza que, durante a década de 1990, a aposentadoria integral ao final da carreira do funcionário púbico era o maior incentivo, visto que o salário defasava-se e aumentava as gratificações no rendimento, que "dependiam mais da força política de cada setor do que do mérito medido por avaliações de desempenho".

Novelli (2010) acrescenta que os reajustes dos servidores públicos no governo Lula foram diferenciados conforme a carreira/cargo, privilegiando aqueles pertencentes ao núcleo estratégico e aos serviços defendidos como exclusivos, de acordo com o estipulado pelo PDRAE. Já Gomes, Barbosa e Silva e Sória (2012) acreditam que as políticas públicas do presidente Lula foram ambíguas, sendo percebidos traços progressistas, voltados aos movimentos sociais, e também aspectos fundamentados na década de 1990, condicionando a totalidade da gestão conforme os limites fiscais.

No atual governo Dilma também é possível ver fortes influências do modelo gerencial. De acordo com Queiroz (2011), várias ações estão sendo tomadas para diminuir os gastos públicos e tornar a máquina pública mais eficiente. A gestão da presidente estaria orientada aos resultados com foco na cidadania. Em relação aos servidores do Poder Executivo, a presidente tem valorizado a meritocracia nos cargos de confiança e de carreira. 
A busca pela eficiência enfatizada pela reforma gerencial modificou a administração pública brasileira após a década de 1990, atingindo também a avaliação dos servidores técnico-administrativos em educação, como abordaremos no tópico a seguir.

\section{A Avaliação de Desempenho nas Organizações}

Após o surgimento do capitalismo, o trabalho do indivíduo e seus resultados passaram a ser limitados ao seu valor de troca. As características concretas próprias de cada pessoa perderam significado para seu equivalente monetário, que as tornou intercambiáveis. Assim, o quantitativo do salário a receber foi interligado ao desempenho do trabalhador. O indivíduo passou a não ser pago conforme o cargo que ocupa, mas, principalmente, em relação ao seu rendimento (PAGÈS, BONETTI, GAULEJAC et al., 2008). Desse modo, muitas das ferramentas que buscam aumentar a produtividade e a redução de custos afetaram diretamente a vida dos trabalhadores. Entre essas práticas administrativas, a avaliação de desempenho ganhou destaque na busca exasperada pela vitória sobre a concorrência (SILVA, 2010).

Segundo Silva (2010), o aumento da demanda por avaliações dentro das organizações está relacionado ao modo de funcionamento da sociedade na atualidade, sob a lógica do capitalismo. Os trabalhadores são avaliados frequentemente e classificados entre "os que não servem", "os que não se adaptam à equipe", "os que têm problemas para se relacionar", até ser rejeitados devido à não aprovação em suas avaliações. De acordo com a autora, existe na atualidade um imperativo de perfeição e excelência no qual a organização ideal deve empregar apenas os trabalhadores felizes, com alta qualificação e que não cometem erros. Como afirmam Faria e Meneghetti (2007c, p. 63), “daí que 'produzir mais que o previsto', 'ser eficaz' e, além disso, 'ser produtivo' encerram uma subjetividade sequestrada no interior da própria lógica competitiva na qual os trabalhadores se envolvem".

Philadelpho e Macêdo (2007) afirmam que as organizações buscam os sistemas de avaliação de desempenho para medir a maneira como o trabalho é desenvolvido em certo período e tem nesse sistema um método de controle do desempenho dos trabalhadores. Desse modo, os autores concebem a avaliação de desempenho como um instrumento de poder que busca controlar e direcionar o comportamento das pessoas por meio da utilização do discurso ideológico das organizações de desenvolvimento dos trabalhadores.

Segundo Pagès, Bonetti, Gaulejac et al. (2008) a administração moderna leva em consideração a realidade apenas por meio de métodos quantitativos e argumentam que os problemas somente podem ser formulados em termos numéricos, sendo que o que é enumerado passa a ser indiscutível, visto que este é considerado científico. Para Faria (2004), a busca pela objetividade com rejeição à subjetividade, por esta não ser considerada ciência, levou ao surgimento de várias formas de domínio psicológico por parte das organizações que recebem apoio das ideologias de gestão capitalista. Essa racionalidade tende a ver o trabalhador somente em função de sua utilidade para a empresa, medindo-a por meio da avaliação quantificada de seu rendimento e da adaptação deste às regras e exigências da organização.

Assim, diante das metas que são estabelecidas, o trabalhador interioriza que é necessário vencer, alcançar os objetivos e dedicar o máximo possível para a empresa por meio da "canalização das energias". Ele é motivado não apenas pelo seu chefe, mas também pelo sistema que aprova por meio das notas positivas, das críticas, todo investimento dado pelo trabalhador no que é considerado bom e recrimina aquilo que é investido para outros fins (PAGÈS, BONETTI, GAULEJAC et al., 2008).

Pagès, Bonetti, Gaulejac et al. (2008) perceberam que quando a empresa demonstra maior interesse pelos trabalhadores, a produção destes se eleva. No entanto, esse aumento de investimento nos trabalhadores faz com que a dominação da empresa sobre o indivíduo se acentue. A avaliação torna-se, então, mais uma situação de exame de consciência do que de reflexão de seus resultados. O que é considerado passa a ser mais o esforço em ser um bom trabalhador do que a qualidade de seu trabalho. Assim, a partir do momento 
que os desejos do trabalhador referem-se ao sucesso e à ambição, a organização consegue satisfazê-los. "O desejo de sucesso, de ser reconhecido como fundamental para a organização, de ter uma identidade, de fazer parte de um projeto social comum, é um dos motivos mais usuais do vínculo à organização" (FARIA e MENEGHETTI, 2007a, p. 293).

Ao disponibilizar um momento para o trabalhador ser ouvido, a organização oferece a possibilidade de este exprimir-se, de admitir seus receios e anseios. Dessa maneira, a organização operacionaliza a administração dos afetos, permitindo seu domínio sobre o psicológico do trabalhador e levando à "dominação psicológica" (PAGÈS, BONETTI, GAULEJAC et al., 2008).

Assim, de acordo com Pagès, Bonetti, Gaulejac et al. (2008), mesmo quando o trabalhador sabe que a avaliação é uma armadilha, ele costuma não recusá-la e defende esse instrumento devido aos grandes princípios, mostrando que existe um sistema de valores dentro da organização. Pagès, Bonetti, Gaulejac et al. (2008) chamam esse comportamento de autopersuasão, ou seja, quando o próprio trabalhador constrói uma justificativa para evitar a manifestação no nível consciente das incongruências nas políticas da organização e, desse modo, desfazer-se das críticas dessas políticas, reforçando desse modo sua credibilidade.

Segundo Pagès, Bonetti, Gaulejac et al. (2008), a avaliação possibilita a expressão pessoal das reivindicações, das angústias e dos planos, reforçando o desconhecimento destes dos outros trabalhadores da organização. O sucesso pessoal torna-se, então, mais valorizado que a solidariedade. Desse modo, ao levar em consideração as reivindicações individuais, a organização evita e reduz as reivindicações coletivas, levando ao que os autores denominam "individuação" por parte dos trabalhadores.

Desse modo, ao tornar a mudança de nível um processo individual, a organização reforça a individuação, aumenta a combatividade e consequentemente a produtividade (PAGÈS, BONETTI, GAULEJAC et al., 2008), levando a uma "valorização da ascensão 'individual' em detrimento da 'coletiva"" (TRAGTENBERG, 1989, p. 33).

Pagès, Bonetti, Gaulejac et al. (2008) ressaltam que o nível, como sistema de codificação, tem por objetivo servir de estímulo e de referência para o desenvolvimento da ambição. Assim, o trabalhador acredita que ao executar bem o trabalho, atingindo seus objetivos, é possível mudar de nível. Diante disso, a promoção não está condicionada à boa vontade de uma chefia compreensiva, mas de um grau que torna a avaliação objetiva. O trabalhador é, então, visto por meio de notas e médias que o caracterizam conforme seu desempenho na organização.

\section{Normatização da Avaliação de Desempenho dos Servidores Técnico-Administrativos em Educação}

A Lei n. 8.112/1990 encontra-se entre os diplomas legais vigentes sobre a avaliação de desempenho dos servidores públicos, alcançando também os servidores técnico-administrativos em educação. Embora essa lei não aborde a avaliação em termos de progressão devido ao mérito, ela cita aspectos que deverão ser avaliados durante o estágio probatório dos servidores, como a assiduidade, disciplina, capacidade de iniciativa, produtividade e responsabilidade.

A Lei n. 8.112/1990 vai de encontro à Constituição Federal (CF), que estabelece a avaliação de desempenho como condição para o servidor concursado adquirir a estabilidade. A CF também estabelece que o servidor estável poderá perder o cargo devido ao procedimento de avaliação periódica de desempenho. Esse inciso foi incluído pela EC n. 19, em 1998, no período em que a reforma gerencial estava sendo implementada pelo governo FHC.

Em termos específicos à carreira dos TAE, a Lei n. 11.091/2005, sancionada pelo presidente Luiz Inácio da Silva, reza que as progressões podem ocorrer por mérito e por capacitação profissional. A primeira é 
realizada mediante resultado positivo na avaliação de desempenho, enquanto a outra depende da obtenção de certificado em programa de capacitação.

No ano seguinte à publicação da Lei n. 11.091/2005 foi instituído o Decreto n. 5.707/2006, que regulamentou a política e as diretrizes para o desenvolvimento de pessoal da administração pública federal direta, autárquica e fundacional. Esse decreto definiu que os resultados das ações de capacitação e a mensuração do desempenho do servidor necessitam ser complementares entre si. Embora esse decreto tenha sido publicado pelo presidente Lula, nele se notam aspectos do gerencialismo defendidos por seu antecessor.

Em continuidade às políticas gerencialistas, em 29 de junho de 2006 foi publicado o Decreto n. 5.825, que estabeleceu as diretrizes para elaboração do Plano de Desenvolvimento dos Integrantes dos Cargos dos servidores técnico-administrativos em educação. De acordo com esse decreto, com o resultado da avaliação de desempenho deve ser possível fornecer indicadores para o planejamento estratégico, assim como buscar o desenvolvimento de pessoal da instituição, proporcionar condições para a melhoria dos processos de trabalho, identificar e avaliar o desempenho coletivo e dos TAE, considerando as condições de trabalho; subsidiar a elaboração dos programas de capacitação e aperfeiçoamento e também o dimensionamento das necessidades da instituição de pessoal e de políticas de saúde ocupacional, assim como estimar o mérito para progressão. Já os instrumentos que são utilizados para a realização da avaliação de desempenho devem ser estruturados observando os princípios da objetividade, legitimidade e publicidade e os outros objetivos, métodos e resultados que foram definidos pelo decreto.

A Lei n. 11.784/2008 reservou um único capítulo para tratar da avaliação de desempenho dos servidores do poder executivo federal, com o objetivo de buscar a melhoria da qualificação dos servidores e subsidiar a política de gestão de pessoas em termos da capacitação, desenvolvimento no cargo ou na carreira, remuneração e movimento de pessoal. De acordo com essa legislação, a avaliação de desempenho dos servidores deve estar relacionada às metas institucionais.

A lei mencionada estabeleceu que as metas de desempenho individual devem ser definidas por critérios objetivos, compondo, assim, o plano de trabalho do setor e ser de comum acordo entre o servidor, a chefia e a equipe de trabalho. Nota-se nessa lei uma busca pelo controle do trabalhador, que deve ocorrer por meio das metas individuais, da equipe e da organização.

A avaliação de desempenho dos TAE nas IFES ocorre, portanto, em duas situações: no período de estágio probatório, embasado na Lei n. 8.112/1990 e na CF, e durante a vida profissional, como estabelecido nas Leis n. 11.091/2005 e 11.784/2008 e nos Decretos n. 5.707/2006 e 5.825/2006, sendo este último tipo de avaliação denominado avaliação por mérito, o foco deste artigo.

\section{A Avaliação de Desempenho na Universidade Federal do Espírito Santo}

Na UFES, a avaliação de desempenho se deu a partir da obrigatoriedade da Lei n. 11.091/2005, sendo a primeira avaliação realizada no ano de 2007. Atualmente, a avaliação de desempenho na instituição obedece à Resolução n. 30/2010, de 22 de agosto, do Conselho Universitário (CUn).

Para realizar a avaliação de desempenho servidor e chefia imediata devem acessar o site da Pró-Reitoria de Gestão de Pessoas no período estipulado anualmente pela universidade. Todos os servidores podem fazer a avaliação de desempenho, inclusive aqueles que já atingiram o último nível de ascensão na carreira, conforme o plano de carreira estipulado pela Lei n. 11.091/2005.

A avaliação de desempenho é dividida em quatro etapas na UFES. A primeira refere-se à "avaliação das condições de trabalho". Preenchido esse formulário, o servidor deve fazer a "autoavalição", "avalição da equipe de trabalho" e "avalição da chefia imediata". Já a chefia imediata que ocupa o cargo de técnico- 
administrativo, além dos formulários indicados, deve preencher para cada um de seus subordinados a "ficha de avalição do servidor".

Para fins de pontuação, a "autoavalição" e "a avaliação da equipe de trabalho" possuem peso 3. Já a "avalição da chefia imediata" tem peso 4 . O primeiro formulário preenchido pelo servidor durante o processo de avaliação "avaliação das condições de trabalho" não interfere na nota final.

O padrão dos formulários utilizado na instituição assemelha-se ao modelo de escalas gráficas, já que os fatores são estabelecidos previamente (GIL, 2001). A nota de cada fator estabelecido varia de 1 a 5 e a nota final da avaliação corresponde à média ponderada desse somatório. O método de escala gráfica segue o princípio da objetivação observado nos estudos de Pagès, Bonetti, Gaulejac et al. (2008), em que sua validade é aceita devido à avaliação quantificada do comportamento do trabalhador. Desse modo, sua aceitação acrítica o torna um dos métodos, de acordo com Dutra (1998), mais adotados na administração pública.

Finalizado o prazo para a avaliação, o servidor pode visualizar sua nota no próprio site da universidade. Caso obtenha nota superior a 3, o servidor obtém a promoção por mérito para o nível seguinte, salvo os servidores que já atingiram o topo da carreira. Ressalta-se que os TAE têm a carreira limitada a 16 padrões de vencimento para progressão devido ao mérito profissional. Ou seja, considerando que a progressão ocorre a cada 18 meses, depois de 24 anos de instituição o servidor não tem como subir na carreira.

\section{Metodologia}

O trabalho desenvolvido foi de abordagem qualitativa, visto que, como afirmam Pereira e Marques (2004), esse tipo de pesquisa considera que há uma relação indissociável entre a realidade e a subjetividade do sujeito. A pesquisa qualitativa também permite uma análise crítica e dialética da realidade social (TRIVIÑOS, 1987).

Optou-se pelo estudo de caso e o lócus analisado foi a UFES. Os sujeitos da pesquisa, servidores técnicoadministrativos em educação das IFES, são divididos em cinco níveis de classificação: A, B, C, D e E. Para a ocupação dos cargos de classe A não é necessário possuir o Ensino Fundamental completo. Na classe B é exigido Ensino Fundamental incompleto ou Ensino Fundamental completo em praticamente todos os cargos. Os cargos da classe C exigem no mínimo o Ensino Fundamental completo, sendo a exigência máxima o Ensino Médio completo com curso profissionalizante. Para os cargos da classe D, em geral, é necessário possuir Ensino Médio completo ou profissionalizante. Já os cargos da classe E podem ser ocupados por profissionais com Ensino Superior ou Ensino Médio completo, com conhecimento especializado na área de atuação ou carta específica. Em alguns casos também são solicitados habilitação e curso de especialização.

Neste estudo, os sujeitos de pesquisa entrevistados foram os servidores técnico-administrativos em educação das classes C, D e E. Os TAE das classes A e B não foram entrevistados, visto que os cargos dessas classes vêm sendo extintos, como disposto nas Leis n. 9.632/1998 e 12.677/2012. Também foram excluídos da pesquisa os servidores ocupantes das classes $C$ e D que ocupam cargos em extinção, como citado nas leis acima. Desse modo, dos 2.225 servidores técnico-administrativos (UFES, 2013b), 145 foram excluídos da pesquisa. Além disso, para realizar a entrevista, os TAE deveriam ter feito pelo menos uma avaliação de desempenho.

Além dos servidores técnico-administrativos em educação, também foram entrevistadas as chefias imediatas da instituição que já participaram da avaliação de desempenho regulamentada pela Resolução n. 30/2010 do CUn. Assim como os TAE, não foram entrevistadas as chefias imediatas cujos cargos vêm sendo extintos.

Os servidores técnico-administrativos em educação e as chefias imediatas participantes desta pesquisa foram selecionados com base no critério da bola de neve. Optou-se por definir o número de participantes por inclusão progressiva, não demarcando no início da pesquisa o número de entrevistados (DESLANDES, 
2007). As entrevistas foram interrompidas conforme o "critério de saturação, ou seja, quando as concepções, explicações e sentidos atribuídos pelos sujeitos começam a ter uma regularidade de apresentação" (DESLANDES, 2007, p. 48).

Para não possibilitar a identificação dos entrevistados, os TAE que realizaram a entrevista são aqui denominados por essa abreviatura somada ao número sequencial das entrevistas (TAE-1 [...] TAE-28); já as chefias imediatas são denominadas pela abreviatura " $\mathrm{CH}$ " somada ao número sequencial das entrevistas (CH-1 [...] CH-11). No total, foram entrevistados 29 técnico-administrativos em educação, sendo que uma dessas entrevistas serviu apenas como teste-piloto, já que algumas perguntas foram modificadas para melhor entendimento do entrevistado. Quanto às chefias imediatas, 11 participaram das entrevistas.

Em relação à caracterização dos entrevistados, TAE e chefias imediatas de ambos os sexos participaram da pesquisa. No que concerne aos TAE, 11 estavam em estágio probatório e 7 tinham mais de 30 anos de instituição. Entre as chefias imediatas, apenas 1 servidor estava em estágio probatório e 2 tinham mais de 30 anos na UFES. Em termos do nível de classificação dos TAE, 2 ocupavam cargos da classe C, 18 da classe D e 8 da classe E. Já entre as chefias imediatas, 2 pertenciam à classe D e 9 à classe E.

Para dar início à produção de dados que pudesse contribuir para a elaboração desta pesquisa, foi realizada uma busca documental para identificar as leis, os decretos e as resoluções que dispõem sobre a avaliação de desempenho no serviço público e na instituição estudada.

Além da análise documental, houve a participação em duas reuniões sobre a avaliação de desempenho promovida pelo Departamento de Desenvolvimento de Pessoas aos TAE em 2012 e 2013. Em ambas as reuniões o assunto tratado foi a avaliação de desempenho e o plano de carreira dos servidores. As anotações ajudaram no entendimento de alguns pontos que são abordados ao longo deste artigo.

Após a produção dos dados pelas fontes descritas acima foram realizadas entrevistas com os TAE da UFES. Optou-se pelas entrevistas semiestruturadas que, de acordo com Triviños (1987, p. 146), partem de questões básicas, sustentadas em teorias e hipóteses, que estão vinculadas à pesquisa, e que posteriormente, "oferecem amplo campo de interrogativas, fruto de novas hipóteses que vão surgindo à medida que se recebem as respostas dos informantes".

Para o tratamento das entrevistas foi utilizada a análise de conteúdo. As entrevistas foram transcritas, analisadas e classificadas dentro de categorias, não definidas a priori, conforme a categorização temática da análise de conteúdo de Bardin (2006). Com base no referencial teórico e na análise das entrevistas foram definidas 5 categorias principais nas falas dos TAE: 1) a insatisfação com a avaliação de desempenho; 2) a importância da avaliação de desempenho; 3) o receio em avaliar a chefia imediata; 4) a subjetividade na avaliação; e 5) a avaliação como sistema de progressão. Já as falas das chefias imediatas resultaram em 4 categorias: 1) a avaliação de desempenho como condição para melhoria do serviço público; 2) a dificuldade ao avaliar; 3) a necessidade de mudanças na avaliação de desempenho; e 4) os sistemas de progressão na universidade.

Análises e Resultados da Pesquisa

A Avaliação de Desempenho a Partir do Entendimento dos Servidores Técnico-Administrativos em Educação

\section{A insatisfação com a avaliação de desempenho}

Após a análise temática das entrevistas realizadas como sugere Bardin (2006), pode-se perceber que há certa consciência dos TAE em relação aos resultados da avaliação de desempenho, o que leva a uma insatisfação 
quanto à política de gestão de pessoas da universidade. Parte desse descontentamento ocorre porque os servidores não visualizam mudanças devido à realização da avaliação, como destacado na seguinte fala:

[...] eu só acho que realmente esta avaliação tinha que servir para melhorar ainda mais o serviço, as condições de trabalho, os parceiros mesmo, ter reunião mais frequente, falar quais são os problemas, acho que a intenção maior de uma avaliação é melhorar e isto não acontece. (TAE-1)

Faria, Schmitt e Meneghetti (2007) ressaltam que essa consciência é fruto do alto custo em aceitar as regras e as normas da organização, o que leva a um questionamento por parte do trabalhador sobre como este está se satisfazendo no trabalho. Desse modo, a consciência pode levar a uma reação negativa diante da organização. Por isso, as empresas procuram criar novos métodos para manter seu controle sobre os sujeitos. Na UFES, a falta de satisfação com a avaliação de desempenho é nítida, sendo apontada por diversas vezes entre os entrevistados.

Apesar da Lei n. 11.784/2008 afirmar em seu artigo 148, inciso IV, que o resultado das condições de trabalho feito pelos TAE poderá ser considerado na avaliação institucional das IFES, é possível inferir que não existe nenhuma análise desse documento por parte da UFES após o término da avaliação de desempenho. Assim, um dos motivos que leva à insatisfação dos TAE com a avaliação de desempenho é a estrutura inadequada para a realização do trabalho. A seguinte fala retratou essa situação:

[...] aqui pra gente ter uma condição de trabalho, às vezes a gente trabalha precariamente e tem que ficar assim, implorando uma condição de trabalho. (TAE-3)

Além de não receber retorno da UFES em relação às condições de trabalho, a maior parte dos entrevistados afirmou não ter ciência de qual encaminhamento a universidade dá para a avaliação de desempenho após seu término. Isso demonstra que os resultados da avaliação de desempenho não são conhecidos pelos servidores, como pode ser observado na seguinte fala:

[...] eu não vejo aplicabilidade disso, a gente não vê os resultados esperados desta avaliação, por isso a gente fica meio descrente com isso. A gente vê que faz a avaliação, entra a avaliação, termina uma, passa outra, sempre as coisas continuam do mesmo jeito.

(TAE-21)

Isso nos remete à discussão de Paula (2005b), cujo argumento demonstra que a inovação na administração pública é questionável, visto que procura aproximar-se das ideias e práticas da administração privada e afasta-se da construção de alternativas administrativas adequadas para o setor público. Desse modo, ao utilizar os modelos de avaliação de desempenho, a administração pública não faz a devida reflexão sobre sua viabilidade para os órgãos em que estão sendo implementados.

Outra questão levantada pelos TAE foi a falta de interesse da UFES na capacitação dos servidores, retratada na seguinte fala:

Por exemplo, conhecimento do trabalho, assim, se é detectado na avaliação que tem pouco conhecimento, então, que seja feito um planejamento de capacitação, ou se o relacionamento interpessoal está ruim, que, trabalhe isso dentro do departamento. Mas eu não vejo isso. Então, eu não vejo que seja só o funcionário sozinho, assim que vai mudar. A gente tem que fazer a nossa parte o máximo que a gente pode, sabe, mas tem que ter os dois lados. (TAE-27) 
Quanto a isso, a Lei n. 11.784/2008 reza que a avaliação de desempenho deve subsidiar a política de gestão de pessoas, em especial, no que concerne à capacitação, ao desenvolvimento no cargo ou na carreira, na remuneração e no movimento de pessoal. No entanto, Faria (2007) aponta que a responsabilidade por buscar novas formas de conhecimento tem sido delegada ao próprio trabalhador como requisito para a manutenção do emprego. Nesse quesito, ressalta-se que o entendimento dos TAE sobre a necessidade de capacitação está mais para uma visão gerencialista, sendo que seus efeitos em termos de apropriação dos conhecimentos do indivíduo ou mesmo do aumento da produtividade sem o retorno igualitário não foi em nenhum momento questionado.

Outro ponto abordado pelos TAE que leva à insatisfação com a avaliação de desempenho é a falta de consideração, por parte da instituição, dos conhecimentos e habilidades do trabalhador:

Talvez assim uma avaliação de desempenho não consiga identificar a vinculação do meu trabalho com o perfil que seria adequado com o trabalho que eu exerço atualmente. Então, assim, eu não conseguiria explorar todo o meu potencial que poderia exercer na administração. Então, a avaliação de desempenho, ela não se presta a isso, para poder explorar o meu potencial ao máximo, ainda que, né, assim, as suas características aí, a questão do desempenho, a questão de postura e tal sejam trazidos, você não consegue porque não consegue identificar estes problemas que têm em relação ao perfil da pessoa com que ela está exercendo atualmente, o perfil profissional dela. (TAE-8)

Assim como nas organizações estudadas por Pagès, Bonetti, Gaulejac et al. (2008), o servidor torna-se isolado diante da organização. Desse modo, se a progressão pelo mérito satisfaz o trabalhador em termos de progressão na carreira, como será evidenciado nas falas das outras categorias, por outro lado as condições de trabalho e sua atuação em funções para as quais não se mostra satisfeito são desconsiderados pela organização, pelas chefias imediatas e mesmo pelos outros colegas de trabalho.

Ao longo das entrevistas, percebeu-se que os servidores ora culpam o governo pela situação em que se encontram, ora acreditam que a UFES é a responsável. Nesse sentido, a fala a seguir destaca que, apesar de não existir legislação específica, a universidade é capaz de oferecer meios para a valorização do trabalhador, embora não demonstre interesse nisso:

Nós aqui, que trabalhamos com áreas estratégicas da universidade, ainda que a área administrativa não seja o fim, mas vai refletir o fim, nós somos administrativos, deveríamos ser melhor reconhecidos nessas atividades. [...] é lógico que eu não estou dizendo remuneração no aspecto de vencimento, porque isso decorre de lei, não é institucional, é nível geral, agora reconhecimento pra quem realmente exerce atividades estratégicas deveria, sim, receber uma função gratificada, né, e como eu disse, aí a gente realmente consegue vislumbrar se esses efeitos do corporativismo que algumas pessoas acabam recebendo porque são amigos de autoridades competentes, né, tem uma amizade com autoridades competentes e outras pessoas que realmente são competentes, são especialistas naquilo que fazem, não são valorizadas, né. $\mathrm{E}$ eu, eu me sinto um alvo disso, né. Eu também me sinto que não pela minha ocupação, pela minha função atual [...] é algo, assim, arriscado. A gente não tem nem o reconhecimento pecuniário nem o reconhecimento, vamos dizer, tácito, daquelas nossas, vamos dizer assim, daqueles superiores que poderiam melhor nos acompanhar, melhor nos conduzir nas dificuldades que a gente tem diárias. (TAE-8)

Assim, verifica-se que após duas décadas do início da reforma gerencial no Brasil, os servidores ainda se encontram insatisfeitos com a política de valorização existente na universidade. Isso contradiz o argumento de Cardoso (1995, p. 7), ao justificar que a reforma era importante para o funcionalismo, visto que seria 
possível "[...] valorizar o servidor público, propiciando-lhe motivação profissional, remuneração condizente com o mercado de trabalho nacional, além de razoável segurança no emprego".

\section{A importância da avaliação de desempenho}

Mesmo sabendo das contradições que a avaliação de desempenho na instituição apresenta, os TAE defendem esse instrumento e acreditam ser uma ferramenta importante para a melhoria do trabalho. Assim, a maior parte dos TAE entrevistados afirmou que a avaliação de desempenho é essencial para o desenvolvimento da organização e, também, para o crescimento profissional dos trabalhadores. Ressalta-se a importância da avaliação de desempenho:

[...] leva a gente a pensar naquilo que a gente tem feito, né?! De razoável e naquilo que a gente pode melhorar, identificar falhas e tudo [...] nos autoavaliar. (TAE-6)

Além disso, os TAE apontaram que a avaliação de desempenho auxilia as chefias imediatas na supervisão de seus subordinados e também os ajuda a enxergar as necessidades dos trabalhadores:

A necessidade da avaliação leva o superior a poder ficar de olho, perceber mais, procurar perceber mais o trabalho dos seus subordinados. Então, eu acho que a avaliação tem essa ação de poder realmente fazer que a pessoa passe a olhar de uma forma mais crítica a quem está subordinado a ela, no caso das chefias imediatas, [...]. Agora ela leva a uma busca por aprender ou descobrir o que os subordinados têm feito. Direcioná-la até melhor pra desempenhar suas tarefas. (TAE-6)

A fala acima representa o discurso de muitos entrevistados de que é necessário um acompanhamento por parte do chefe em suas atividades. Para Faria e Meneghetti (2007b), ao aceitar as formas de controle nem sempre o trabalhador faz a devida reflexão sobre elas. Assim, a maior parte dos indivíduos não procura questionar as práticas de controle utilizadas em seu trabalho.

Leal e Schmitt (2002, p. 1) afirmam que "o que impera nas interações entre indivíduos, organizações e Estado é o utilitarismo, a racionalidade e a aceitação como verdade apenas do que pode ser comprovado empiricamente", argumento que pode ajudar a entender essa aceitação da avaliação de desempenho como um instrumento válido e importante para a gestão pública. Além disso, ao aceitar as práticas gerenciais, o indivíduo se submete à dominação da organização, de forma inconsciente, e essa dominação se torna cada vez mais forte com a dissolução da instância crítica do trabalhador (PAGÈS, BONETTI, GAULEJAC et al., 2008).

É importante ressaltar que durante as entrevistas os TAE não questionaram a validade da avaliação de desempenho. Para eles, o instrumento tem seu mérito e deve continuar sendo utilizado no âmbito público, sendo considerado um sinônimo de progresso nas políticas de gestão de pessoas. A seguinte fala sintetiza esse argumento:

Começou em uma direção que pra mim é correta, a direção para mim tem que ser esta mesma, vai avaliando, vamos evoluindo, é, a ferramenta é excelente, se ela for bem aplicada, bem gerenciada, fica ótimo. Você vai descobrir seus pontos fortes, pontos fracos, atacar os pontos fracos, só vai evoluindo profissionalmente, eu acho que tem tudo para dar certo, sim. (TAE-20)

Ao refletir sobre seus pontos fracos, o indivíduo acredita que a avaliação de desempenho contribui para seu desenvolvimento. Nesse sentido, Pagès, Bonetti, Gaulejac et al. (2008) acrescentam que existe uma ideia nas organizações de que o trabalhador pode estar superando a si próprio quando cresce na carreira, quando, na verdade, são os objetivos da organização que estão sendo alcançados. 
Pagès, Bonetti, Gaulejac et al. (2008) afirmam que o trabalhador, por meio de sua autopersuasão, cria uma justificativa para evitar a consciência das contradições nas políticas da organização, de modo a desarmar a crítica dessas políticas e, assim, reforçar sua credibilidade. Mesmo não estando completamente satisfeito com a avaliação, o servidor acredita que ela é necessária para seu desenvolvimento.

\section{0 receio em avaliar a chefia imediata}

Embora haja uma aprovação da utilização da avaliação de desempenho por parte dos TAE, eles têm receio de avaliar a chefia imediata. Nesse sentido, os TAE têm consciência de que esse tipo de avaliação pode provocar transtornos em seu trabalho e, por isso, existe o medo de sofrer punições. Há certa cautela dos TAE em relação à avaliação de desempenho, ao que deverá ser dito sobre a chefia imediata. A prudência com aquilo que se diz é típica das organizações hipermodernas, de acordo com Pagès, Bonetti, Gaulejac et al. (2008). A seguinte fala demonstra a preocupação quanto à avaliação da chefia imediata:

[...] não fica claro se a chefia vai ou não ter acesso a esses resultados e avaliar negativamente o chefe pode gerar consequências políticas em relação a isto. A pessoa pode ser tirada do setor ou ter a avaliação ruim na próxima vez, então, não dá para fazer a avaliação ruim por causa disto, por conta de sofrer possíveis retaliações. (TAE-2)

Afirma-se haver dúvida acerca de como a chefia imediata acessa o sistema da universidade para verificação da nota e como ela pode reagir diante das críticas recebidas. Ou seja, a maneira como os dados serão obtidos pela chefia imediata não são suficientemente claros. Nota-se que no site da Pró-Reitoria de Gestão de Pessoas da universidade existe uma série de respostas sobre a avaliação de desempenho (UFES, 2013a), mas em nenhum momento a questão de sigilo das respostas do servidor diante das chefias imediatas é abordada. Assim, a avaliação de desempenho apresenta-se para os TAE de forma "gratificante" e "ameaçadora" (PAGÈS, BONETTI, GAULEJAC et al., 2008). Gratificante porque a nota positiva na avaliação pode levar à progressão devido ao mérito, mas, ao mesmo tempo, ameaçadora porque a maneira como o servidor se expõe pode prejudicar o relacionamento que ele tem com a chefia imediata, como evidenciado na seguinte fala:

[...] eu fico com um pouco de receio assim na hora que eu vou avaliar ali as notas, eu não sei, assim, aquilo que eu te falei, será que quando ela [a chefia imediata] abre lá o sistema aparece a nota que eu dei para ela nesse quesito? Entendeu?! Eu tive um amigo, por exemplo, que ele avaliou a chefia dele e [...] deu uma nota baixa, que considerava baixa, e a chefia deu a mesma nota pra ele, aí foi na época ele falou comigo: "não tem como ele ver a minha nota". Aí eu falei: "não pode ser coincidência nas médias". E ele falou "a coincidência é muito grande". Então, por exemplo, eu tenho receio dela [a chefia imediata] estar vendo a minha nota, aí tendo receio eu acabo avaliando por cima. Eu não vou avaliar por baixo. [...] é aquela teoria, né, se ela vir ou não, mas se ela ver eu vou garantir. Aí eu acabo avaliando por cima. Teria pontos que eu acho que eu deveria tirar mais pontos, mas eu acabo não tirando, eu acabo deixando por cima, naquela média entre 4 e 5 que todo mundo faz e fica ali. (TAE-11)

De acordo com informações do Departamento de Desenvolvimento de Pessoas, a chefia imediata não recebe a nota de cada servidor, mas, sim, a média decorrente da avaliação de todos aqueles que estão sob seu comando. Assim, não é possível identificar as notas dadas por determinado servidor na avaliação de desempenho. No entanto, quando o setor não possui mais de um servidor, situação muito comum na universidade quando se trata de secretarias de departamentos, colegiados e pós-graduação, o servidor acaba sendo exposto, visto que não existe outra pessoa em seu setor para ser avaliada.

Pagès, Bonetti, Gaulejac et al. (2008) afirmam que, ao criar meios para que a pessoa possa se expressar, a organização evita a emergência de canais de expressões coletivas que poderiam fugir de seu controle. Assim, há uma individualização do descontentamento onde o trabalhador não exprime seu mal-estar diante de uma 
organização que o incentiva nesse sentido, passando este a se apegar a si próprio quando esse sentimento se acentua. A seguinte fala ilustra essa situação em termos de sua participação na avaliação de desempenho:

Eu não consigo ser sincera, porque eu acho que a pessoa não vai entender o meu ponto de vista, mas eu tenho que entender o dela. E cria um mal-estar também porque eu não concordo com alguma coisa que ela tenha me avaliado mal, mas que vai ficar por isso mesmo, porque ela é a chefe. (TAE-10)

Nesse sentido, durante a análise das falas dos entrevistados, foi possível perceber que o receio de ser penalizado ao fazer a avaliação da chefia imediata ocorre mesmo com os servidores que já finalizaram o estágio probatório e que já tiveram sua estabilidade assegurada. Isso nos ajuda a inferir que o medo de ser mal avaliado ao fazer uma crítica à chefia imediata acaba sendo um sentimento comum aos servidores.

\section{A subjetividade na avaliação}

Para os TAE não existe imparcialidade na avaliação e julgam que isso é decorrente do serviço público. Nesse sentido, é possível afirmar que, embora exista um sistema de avaliação de desempenho elaborado, como sugere o PDRAE (BRASIL, 1995), na prática, não se visualiza critérios quanto à nota que os servidores recebem. Isso leva os TAE a acreditar que o melhor caminho é ter uma avaliação que condicione o desempenho às metas previamente definidas, situação comum nas organizações privadas, como se essa condição fosse a panaceia para os problemas do serviço público. A seguinte fala aponta um dos problemas da avaliação de desempenho na UFES:

Se a gente partir do princípio que a avaliação é impessoal, imparcial, aí realmente partiria ali das características do potencial, do bom desempenho do avaliado, né. Então, assim, se você bem desempenhar as suas funções seria a premissa. Mas, infelizmente na administração pública a gente padece desse corporativismo, então, grande parte das vezes é o que acontece na avaliação de desempenho basta você ter um bom relacionamento interpessoal com as partes envolvidas que você vai ter um resultado assim, gradiente assim, alto, escore alto, vamos dizer assim. Então, a teoria ela percorre um caminho que infelizmente a gente não goza, não experimenta dessa teoria, principalmente por esse vício que tem na administração que é o corporativismo. Então, hoje para você atingir esse resultado bom, um resultado alto e esperado basta você ter uma boa amizade, vamos dizer, influência pessoal com as partes interessadas. (TAE-8)

Pode-se dizer que, na universidade estudada, a avaliação está diretamente relacionada à proximidade da chefia imediata com seus subordinados, apesar desse aspecto não ser aprovado pelos servidores. Assim, a maneira como os TAE são avaliados acaba fugindo da racionalidade defendida pela reforma gerencial, embora as resoluções que tratam sobre a avaliação de desempenho na UFES e as legislações que rezam sobre o assunto orientam que as metas sejam estabelecidas no âmbito da universidade para a política de mérito. Caso isso fosse seguido, a remuneração do trabalhador estaria condicionada às metas definidas junto à instituição, não indicando necessariamente que seria o melhor caminho para os problemas apresentados pelos TAE.

Os TAE também acreditam que a nota na avaliação de desempenho pode ser fruto de uma competição entre os próprios servidores na disputa por um melhor relacionamento interpessoal com a chefia imediata. $\mathrm{Na}$ organização analisada por Pagès, Bonetti, Gaulejac et al. (2008), a competição ocorria devido à questão das metas, isolando completamente os indivíduos uns dos outros. Em relação à UFES, a avaliação de desempenho leva a uma competição velada, onde o relacionamento entre chefia imediata e o servidor pode ser motivo de disputa. Assim, é possível inferir de que independentemente da maneira como ocorre e por qual motivo, a avaliação de desempenho resulta em uma forma de competição entre os trabalhadores, como demonstrado no seguinte trecho: 
[...] existe muito coleguismo dentro do serviço público, sempre tem alguém que é mais chegado à chefia ou mais chegado aos colegas, sempre tem um grupo que é mais fechado, né, acho que nesse caso aí você sente diferença, né, na avaliação. Um é mais chegado na chefia, outro já não é, ou existe uma competição às vezes também, né, de colegas de muito tempo de serviço, isto é nítido de se ver. (TAE-22)

Nota-se nas falas uma proximidade com as atitudes que ocorrem nas empresas hipermodernas (PAGÈS, BONETTI, GAULEJAC et al., 2008), onde os trabalhadores devem correr atrás de seus objetivos, que no caso dos TAE é a progressão, sem saber como estão os outros colegas, ou seja, sem ter conhecimento de que forma eles serão avaliados. Se na empresa hipermoderna há uma negociação individual em relação aos objetivos que devem ser atingidos, no caso da instituição a negociação ocorre de acordo com a amizade entre chefia imediata e servidor.

Também se observa nas falas dos TAE que, ao contrário da organização estudada por Pagès, Bonetti, Gaulejac et al. (2008), a mudança de nível depende mais do interesse da chefia imediata em conceder uma nota do que da objetivação da avaliação. Assim, embora a administração gerencial busque que os órgãos públicos tenham um modelo de gestão similar à organização estudada por Pagès, Bonetti, Gaulejac et al. (2008), na qual as amizades não influenciavam na avaliação de desempenho, na UFES não é possível separar o grau de amizade entre TAE e chefia imediata durante o processo de avaliação

A influência da amizade no relacionamento profissional dos TAE vai de encontro também ao discurso de Paula (2005b), ao afirmar que, apesar de haver um discurso da vertente gerencialista na reforma do Estado, não há como comprovar que o gerencialismo elimine o patrimonialismo. De acordo com a autora, condenar as práticas patrimonialistas e aderir à visão gerencialista não é suficiente para haver mudanças. Nota-se, dessa maneira, que a avaliação de desempenho na instituição estudada não inibe os privilégios, como defendido por Dutra (1998).

Como não aprovam a subjetividade existente na avaliação de desempenho utilizada na universidade, os TAE procuram um instrumento que possa ser neutro, que ofereça, na visão deles, maior cientificidade e esperam que os resultados da avaliação de desempenho sejam comprovados por meio de dados estatísticos. Nesse sentido, Pagès, Bonetti, Gaulejac et al. (2008) lembram que, nas organizações hipermodernas, a objetivação é amparada por uma linguagem matemática que busca ser universal e científica e que pode ilustrar as técnicas de poder que a encobrem. Ressalta-se que os TAE não apontam nenhuma dúvida quanto à validade desse método nem questionam quais consequências pode trazer, como observado na seguinte fala:

[...] eu acho assim, eu percebo, ah, basta o cara ser gente boa, ah, ele não cumpre o horário dele, mas ele é gente boa, entendeu, não se preocupa muito em mensurar, acho que a gente não tem aquelas ferramentas para mensurar produtividade, infelizmente [...]. (TAE-11)

Assim, a partir das falas dos TAE pode-se dizer que eles acreditam que basta quantificar para que os problemas sejam resolvidos, compartilhando uma visão que é comum nas organizações (PAGÈS, BONETTI, GAULEJAC et al., 2008).

\section{A avaliação como sistema de progressão}

O fato de a avaliação de desempenho ser requisito para a progressão funcional é considerado um aspecto importante para que o servidor participe da avaliação. Ou seja, o sistema de avaliação atual acaba tendo maior utilidade para a progressão individual, não sendo percebida qualquer outra contribuição, a não ser o pecuniário para o servidor, como destacado nesta fala:

Eu julgo que o nível assim institucional da avaliação ela está mais para formalizar a lei para progressão do que está preocupada com ambiente em si de trabalho. Por exemplo, eu nunca 
vi no final quando você avalia um setor, o superior, ou os que estão interagindo no mesmo nível sentarem para conversar sobre o resultado daquela avaliação. A gente lança no sistema, depois você tira lá o espelho do resultado da sua avaliação, e morreu ali, né [...], eu nunca vi utilidade naquilo ali a não ser formalizar perante a lei para progressão, é a visão que eu tenho assim. (TAE-11)

Para aqueles TAE com maior tempo de serviço na instituição, que já chegaram ao topo da carreira, não foram expostos motivos para realizar a avaliação de desempenho. Os TAE que atingiram o vencimento máximo na carreira não se importam com a avaliação de desempenho, conforme demonstrado na fala abaixo:

Essa avaliação não faz [diferença] na minha tabela de progressão [...], eu acho que o governo deveria rever isto aí, porque a gente estacionou, chegou ali estacionou e igual a avaliação pra quê? Se não serve nada pra gente, pra quem está entrando talvez possa servir, mas pra gente? Igual a um professor que chega ao final de carreira, vai fazer avaliação do docente pra quê? (TAE-3)

Já para os TAE com menor tempo de instituição, atingir a progressão é fator primordial, sendo que eles tentam obter um nível superior a qualquer custo, mesmo quando não concordam com a avaliação realizada. A seguinte fala ilustra a falta de questionamento em relação à avaliação de desempenho:

Quando ela perguntou o que eu achava eu falei "tá bom”. Eu só vi que o total dava para eu pedir uma progressão, e aceitei. Se não tivesse chegado na média pra pedir uma progressão aí eu teria reclamado, mas como dá para pedir uma progressão tranquilamente, então, deixa para lá, eu não questionei não. (TAE-10)

Para Pagès, Bonetti, Gaulejac et al. (2008), a partir do momento que o sucesso torna-se um valor em si, os questionamentos sobre as finalidades e os critérios passam a não ser importantes. Desse modo, para os TAE, o sucesso está vinculado à progressão, sendo que a maneira como a avaliação é realizada não é considerada.

Em relação à avaliação, a maioria dos TAE disse estar satisfeita com a nota que lhe é atribuída, e poucos deles disseram que costumam questioná-la. Ou seja, o questionamento à chefia imediata existe somente se a nota não corresponde ao mínimo atribuído para a progressão. A importância da avaliação de desempenho para os TAE está, portanto, em seu aspecto financeiro. Como ressaltam Pagès, Bonetti, Gaulejac et al. (2008), os valores do trabalho foram substituídos pelo dinheiro, o qual suborna os valores da coletividade e do indivíduo. Desse modo, nota-se que a avaliação de desempenho tornou-se condição necessária para que muitos servidores consigam ter um aumento salarial.

Percebe-se, também, que, ao utilizar a avaliação de desempenho como sistema de progressão individual, a organização leva o trabalhador a aceitar o sistema, evitando, desse modo, as reivindicações coletivas, como afirmam Pagès, Bonetti, Gaulejac et al. (2008). Assim, não existe preocupação em relação à nota dos demais TAE, mas, sim, a fatores que prejudicam o crescimento do avaliado. Além disso, segundo os autores, ao transformar a mudança de nível em um sistema de codificação a organização estimula o desenvolvimento da ambição, como ilustra esta fala:

[...] a equipe talvez eu não a ache tão boa, mas, aí, se eu der a nota da equipe eu vou estar prejudicando a minha nota também. Então, esse sistema acaba tipo fazendo com que a gente não leve tão a sério a avaliação da equipe, como deveria ser, eu acho. Porque você acaba se preocupando mais com você mesmo do que com a equipe. (TAE-9)

Observa-se que a nota da avaliação da equipe é uma média de todos integrantes do setor. Assim, a avaliação que o servidor faz dos seus colegas influenciará em seu resultado final. Nesse sentido, Paula (2005b) afirma 
que existem comprovações de que o sistema de carreira na administração pública é muito individualista, existindo, desse modo, uma disposição à defesa dos interesses individuais, sendo que o próprio Estado promove o individualismo e não o indivíduo (TRAGTENBERG, 1989).

\section{A Avaliação de Desempenho a Partir do Entendimento da Chefia Imediata}

\section{A avaliação de desempenho como condição para melhoria do serviço público}

A maior parte das chefias imediatas disse ser favorável à avaliação de desempenho e cita uma série de fatores que a torna importante no serviço público. Assim, um ponto destacado foi que a avaliação de desempenho pode melhorar o desempenho dos TAE, conforme o trecho a seguir:

[...] você acaba visualizando o que você está fazendo de errado. Você consegue enxergar os resultados depois. Então, eu acho que é uma ferramenta para te avisar naquilo que você está falhando. Para você corrigir o direcionamento. Eu mesmo já fiz isso. (CH-1)

Verifica-se que o discurso das chefias imediatas, assim como dos TAE, está voltado a uma lógica gerencialista e o entendimento delas corrobora a visão do PDRAE (BRASIL, 1995). Desse modo, as chefias imediatas e os TAE defendem que a avaliação de desempenho é importante para que o trabalhador reflita sobre seu desempenho e, desse modo, procure formas de melhorar sua produtividade. No entanto, falta por parte dos entrevistados um entendimento crítico sobre as consequências que podem emergir da avaliação de desempenho, caso estas sejam seguidas como dispõe a legislação.

Para a chefia imediata, a avaliação de desempenho é uma atividade obrigatória do servidor e é com a ajuda dela que os TAE têm que buscar maneiras de melhorar seu desempenho, como apresentado na seguinte fala:

Se a pessoa tiver um pouco de prudência, vontade, ela até vai verificar os pontos em que ela deixou a desejar e que ela pode e deve cumprir mais, que eu acredito que é sempre possível melhoria, ela vai correr atrás [...]. (CH-3)

Essa necessidade de buscar meios para que o servidor público fosse avaliado foi fortemente enfatizado pelo PDRAE na década de 1990, com a justificativa de que os trabalhadores são egoístas e aéticos, de forma que somente o controle das atividades desenvolvidas no trabalho permitiria a proteção da coisa pública (BRASIL, 2009). Com esse discurso, essencialmente funcionalista, defendeu-se que a avaliação é sinônimo de qualidade.

A necessidade de estar sempre buscando melhorias, como indica a fala da $\mathrm{CH}-3$, é uma característica das organizações hipermodernas, que dependem cada vez mais da iniciativa dos trabalhadores, com sua adesão intelectual e impulsiva para aumentar sua produtividade. Entretanto, ao mesmo tempo deve haver novos instrumentos de controle político, ideológico e psicológico do trabalhador (PAGÈS, BONETTI, GAULEJAC et al., 2008).

Outro aspecto evidenciado na fala das chefias imediatas foi a necessidade de acompanhamento periódico dos TAE. Ressalta-se nesse quesito que a Resolução n. 30/2010 do CUn também estabelece que a avaliação de desempenho na instituição deve promover um gerenciamento de forma contínua e sistematizada do desempenho do servidor. Nota-se, aqui, que embora não exista uma política de metas na instituição, legislação e chefias imediatas compartilham que o controle do trabalhador deve ser exercido. A ideia é abordada nesta fala: 
A gente volta para aquele ponto, se a gente tiver tempo e trabalhar mais diretamente com a pessoa, ou então chamá-la [...] para falar “ô, fulano, como é que está aquilo?”. Como é que você está indo, se você tiver um acompanhamento passo a passo ali eu acredito, de outra forma eu acho que não é possível [melhorar o desempenho do servidor]. Você tem que ter este contato [...] desde que seja feito com acompanhamento e não muito longo, né, de um e um mês, uma vez por mês você se encontrar, fazer uma reunião, né, bater um papo, acompanhar e não só delegar e deixar para lá, dessa forma eu acho que dá, sim (CH-3)

Sem demonstrar uma reflexão em termos críticos, as chefias imediatas consideram a avaliação de desempenho um avanço na administração pública, ajudando, assim, a difundir os fundamentos do PDRAE de que esse instrumento é essencial na administração pública (BRASIL, 2009). A fala a seguir ressalta a importância para as chefias imediatas da utilização da avaliação de desempenho na UFES:

Eu achei importante porque até então [...] não tinha essa avaliação e a partir do momento que foi inserida melhorou muito, eu acho que é válido, sempre que eu sou convidado a participar eu estou pronto para participar e trabalho junto com os meus servidores e ajudo na melhor maneira possível, incentivo até, vou às reuniões, participo, depois faço uma avaliação, no tempo correto e tudo certinho. $(\mathrm{CH}-10)$

As chefias imediatas também afirmam que uma vantagem do uso da avaliação de desempenho é possibilitar que o subordinado diga ao seu superior como este está desenvolvendo seu trabalho, criando, assim, uma visão deturpada de que os TAE podem expressar sua opinião junto à organização, como indica a seguinte fala:

Você passa a verificar as possíveis necessidades que o servidor tem para desenvolver certos tipos de trabalho, né. Como ele também pode estar avaliando se o próprio chefe também está no caminho certo naquilo, que eles também acham, porque eles têm a liberdade de se expressar. (CH-7)

Nota-se que, de acordo com Pagès, Bonetti, Gaulejac et al. (2008), o argumento de que os trabalhadores podem expressar sua opinião é uma estratégia das organizações para impor seu domínio, visto que, ao participar da avaliação, o trabalhador sente que pode modificar sua trajetória e que também está sendo ouvido.

Assim, diante do entendimento de que a avaliação de desempenho é fundamental na administração pública, as chefias imediatas defendem que esta seja mais bem divulgada, porque somente a partir de uma melhor aceitação é que seus efeitos poderão ser sentidos, conforme ilustra esta argumentação:

Eu acho que tem que refletir melhor, trabalhar melhor o quão bom é a avaliação de desempenho. Porque a partir do momento que todo funcionário, todo chefe se conscientizar disso, o quanto é bom a avaliação de desempenho, talvez ela vai ter mais efetividade [...]. (CH-6)

Pagès, Bonetti, Gaulejac et al. (2008) afirmam que a contribuição dos indivíduos para as políticas das organizações está fortemente relacionada com sua integração ideológica. Assim, essa ideologia se desenvolve conforme a sofisticação dos dispositivos técnicos e ideológicos que as organizações dispõem. Desse modo, pode-se dizer que há uma vontade por parte das chefias imediatas de construir uma imagem com os TAE de que a avaliação de desempenho é condição necessária para o trabalhador, já que, na universidade estudada, os fundamentos gerencialistas da avaliação parecem não ter sido assimilados. Logo, quanto maior a aceitação por parte dos TAE da avaliação de desempenho, maior será a dominação da organização sobre eles. 
Para as chefias imediatas, portanto, a avaliação de desempenho tem grandes méritos. Ou seja, não há aspectos negativos a apontar sobre o instrumento ou o próprio sistema de gestão de desempenho quando seguidos seus fundamentos gerencialistas. O problema é mais específico, em termos locais, como se pode verificar nas outras categorias.

\section{A dificuldade ao avaliar}

As legislações vigentes rezam que a avaliação de desempenho deve ser realizada na observância de critérios objetivos. Seguindo essa lógica, uma das dificuldades apontadas pelas chefias imediatas é conseguir atender às normativas acerca da avaliação de desempenho, atendendo ao requisito da objetividade. A argumentação a seguir ilustra esse entendimento:

Minha maior dificuldade, eu não sei. Talvez a existência de alguns critérios subjetivos que seriam difíceis de mensurar, ou algo assim. (CH-2)

Pagès, Bonetti, Gaulejac et al. (2008) ressaltam que, nas políticas de avaliação, a questão da objetivação, ou seja, a utilização de dados quantitativos para medir o rendimento do trabalhador e verificar a adaptação dele às regras e mecanismos da organização, é muito utilizada. Há, no entanto, ao contrário dos TAE, uma vontade por parte das chefias imediatas para que essa avaliação também considere as questões subjetivas. $\mathrm{O}$ trecho da entrevista do $\mathrm{CH}-1$ caracteriza essa situação:

Eu acho que é uma maneira, mas não seria talvez somente ela ou a melhor, entendeu?! Eu acho que como ela é objetiva, né, ela é objetiva, não é? Ela deveria ter algum parâmetro, ali, para você escrever alguma coisa mais subjetiva, entendeu? (CH-1)

Além da objetivação, outra dificuldade analisada nas falas das chefias imediatas é a preocupação em termos da "igualdade de todos diante da avaliação", que, de acordo com Pagès, Bonetti, Gaulejac et al. (2008), são os fundamentos que orientam a elaboração e utilização das medidas de desempenho. As chefias imediatas se cobram para que não exista qualquer diferença entre os subordinados, ou seja, que os servidores avaliados tenham a mesma oportunidade, opinião esta que, segundo Pagès, Bonetti, Gaulejac et al. (2008), é muito comum nas organizações capitalistas, já que os trabalhadores devem ter o mesmo direito de vencer. Essa situação pode ser ilustrada com a seguinte fala:

[...] eu não posso extrapolar as limitações de cada servidor, e não posso também tratá-los de forma diferente, em minha opinião os servidores têm que ser tratados de forma igualitária, todos os subordinados. Então, na medida em que este tratamento é justo, que eu não venha em sacrificar um em detrimento de outro, e que venha a tratar todos com igualdade, na minha opinião é o caminho para se ter uma boa nota. (CH-4)

Para as chefias imediatas, não é fácil realizar a avaliação de desempenho, mesmo acreditando que ela seja fundamental para o desenvolvimento do servidor. Assim, verifica-se que a chefia imediata apenas tenta reproduzir as técnicas de gestão (PAGÈS, BONETTI, GAULEJAC et al., 2008) que são definidas por meio das legislações. Desse modo, mesmo apresentando dificuldades em fazer a avaliação não é possível recusálas, visto que esta é considerada uma atividade daqueles que estão em função de chefia. Como afirmam Pagès, Bonetti, Gaulejac et al. (2008), acima de qualquer decisão, as chefias devem submeter-se às regras, às políticas e aos dispositivos da organização, como destacado na fala do CH-9:

[...] nem é questão de gostar ou deixar de gostar, questão que a gente sabe que uma tarefa que a gente tem que gostar de cumprir, e tem que fazer, não tem como. (CH-9) 
No entendimento das chefias imediatas, a responsabilidade de lidar com os problemas que podem surgir, caso exista uma nota não favorável à progressão, é outra dificuldade do processo de avaliação. Nesse aspecto, é possível questionar o governo brasileiro por afirmar que a vantagem do uso da avaliação de desempenho é que esta estimula a comunicação entre o trabalhador e sua chefia, além de promover maior participação e harmonia no local de trabalho (BRASIL, 1995). A seguinte fala expõe essa dificuldade:

É aquele zum, zum, zum, aquele burburinho, entendeu, você avaliou direito, você não avaliou direito, você não avaliou direito o subordinado, eu já estou falando das duas condições, às vezes os subordinados não gostam muito, então, é difícil, às vezes você até quer dar uma nota que não seja boa, acho que não é boa, mas pelo que eu já vi da universidade, ah, como você não deu uma nota boa? Ah, quem acaba ficando mal visto não é o servidor, é o chefe. (CH-6)

Como avaliar o servidor por meio de conceitos também foi questionado pelas chefias imediatas, já que para elas a maneira como os TAE são classificados motiva a competição, tornando a questão da progressão ainda mais individualista, como comentado na seguinte fala:

[...] as pessoas são muito motivadas pelos conceitos, né, e não levam em consideração o que de fato elas produzem, deixaram de produzir. Por isso, eu acho um tanto quanto reducionista este lance de trabalhar com conceitos. E eu não sei se caracteriza um bom elemento para a avaliação porque pode gerar atrito, sobretudo entre pessoas do mesmo nível. (CH-11)

Para muitas chefias imediatas, a dificuldade de realizar a avaliação de desempenho decorre também da própria diferença que existe entre o trabalhador da administração pública ao da iniciativa privada. Assim, nota-se que, com a política da reforma gerencial, que buscou aplicar as práticas das organizações privadas no setor público, essas comparações tornaram-se inevitáveis, como apontado pelas chefias:

[...] eu acho que ela tem que existir, tem que ter a avaliação de desempenho, e a avaliação de desempenho talvez tenha que melhorar logo no estágio probatório [...] Então, isso aí é uma coisa que eu acho que tem que ser trabalhado muito aqui no serviço público, eu sempre, não é que eu me interessei, mas eu sempre olhei muito por essa área, pra você ver, eu nunca trabalhei na iniciativa privada mas sempre no serviço público, mas eu acho que cada dia mais o serviço público tem que pegar algumas práticas da iniciativa privada. $(\mathrm{CH}-$ 6)

Para as chefias imediatas, uma nota que não seja favorável ao trabalhador pode gerar um desconforto no local de trabalho, já que muitos servidores não aceitam a avaliação que recebem. Esse é, portanto, outro ponto, no entendimento das chefias imediatas, que dificulta a realização de uma avaliação de desempenho dentro dos fundamentos gerencialistas. A manifestação da chefia imediata reflete essa situação:

Eu já vi, aqui [...] outras pessoas, nossa, ficaram mal, teve gente que ficou doente, então, às vezes você acha que a pessoa não está bem, aí você fala com a pessoa, a pessoa não gosta, acha que não é aquilo e aquilo, a pessoa não trabalha, a pessoa chora e a pessoa... É complicado. Eu acho avaliação muito complicada. Não é todo mundo que aceita, né, uma coisa ruim, quando é bom todo mundo acha ótimo, agora quando é ruim, é muito difícil. O ser humano é difícil. (CH-5)

É importante ressaltar que quase todos os entrevistados indicaram a preocupação com a atitude dos TAE diante dos resultados na avaliação de desempenho. Ou seja, existe uma dúvida por parte das chefias 
imediatas entre seguir as normas da instituição ou atender aos objetivos individualistas dos TAE em termos de querer progredir na carreira.

Assim como o sentimento dos trabalhadores quanto à organização estudada por Pagès, Bonetti, Gaulejac et al. (2008), as chefias imediatas têm um entendimento ambivalente em relação à avaliação de desempenho. Enquanto existe uma simpatia em relação à avaliação, sendo esta fonte de esperança para a melhoria do serviço público, por outro lado há uma angustia ao utilizá-la, devido aos problemas que pode ocasionar nos setores de trabalho.

Outro ponto observado nas entrevistas é a dúvida em relação às notas da avaliação de desempenho, já que tanto as chefias imediatas como os TAE se sentem constrangidos em avaliar os outros servidores. $\mathrm{O}$ depoimento a seguir contextualiza essa situação:

É aquilo que eu te falei, às vezes o próprio colega não vai querer dar uma nota baixa para o seu colega do lado, porque se você acha que vai ficar com cara feia, não vai entender, por isso tem que ser trabalhada melhor a avaliação de desempenho. Por que você está sendo avaliado? Talvez aí não tenha tanta influência [...]. (CH-6)

Em relação às falas acima, como já observado no discurso dos TAE, embora a chefia acredite que um servidor não queira avaliar o outro para não promover uma insatisfação, o que está em jogo é a questão da individualidade, ou seja, o quanto a avaliação de desempenho vai influenciar no resultado final. Ou seja, sabe-se que avaliando mal seu colega o servidor também será prejudicado, visto que as notas estão atreladas na avaliação de equipe. Isso demonstra que a avaliação de desempenho pode promover a individuação. Assim, mesmo que não haja metas claramente definidas na organização, existe uma busca para que cada um atinja o objetivo esperado, ou seja, a progressão.

\section{A necessidade de mudanças na avaliação de desempenho}

Para as chefias imediatas, entre as mudanças necessárias na avaliação de desempenho deve estar a maior integração da universidade com as políticas de desempenho, ou seja, procurando meios de efetivar as práticas gerencialistas. A seguinte fala caracteriza essa demanda por parte das chefias:

[...] por que será que a competência fica só para mim como chefe para eu tentar motivar, tentar fazer com que ela trabalhe melhor? E da instituição como formadora também? Porque antes dela pertencer a um setor ela pertence a uma instituição também. E cadê as políticas de motivação que possam melhorar a qualidade do trabalho dela? (CH-11)

As chefias imediatas apresentam vários argumentos que indicam que a avaliação de desempenho deve passar por mudanças. Nesse sentido, quase todos os entrevistados apontaram alguma necessidade. No entanto, mesmo não estando satisfeitas, as chefias imediatas aceitam a avaliação de desempenho como um processo em construção, que está sendo mudado aos poucos, ou seja, existe uma prática gerencialista que vem sendo difundida no serviço público. O seguinte depoimento caracteriza essa situação:

É melhor, é um ponto forte da instituição nesse período, agora atualmente, porque logo que eu entrei na UFES não existia a avaliação de desempenho, então, é melhor do jeito que está do que sem nenhuma, mas ela pode, sim, poderia ser melhorada. $(\mathrm{CH}-2)$

Uma das necessidades mais destacadas pelas chefias imediatas foi a maior participação da instituição nas políticas de gestão de pessoas, sendo que, para estas, a universidade não contribui muito para a expansão da aceitação da avaliação de desempenho junto aos TAE. Nota-se novamente nesse aspecto que as chefias imediatas cobram de forma acrítica uma maior difusão dos aspectos gerencialistas da avaliação de desempenho. A seguinte manifestação da chefia imediata ilustra essa situação: 
[...] eu acho que até os chefes eles tinham que, eu me coloco talvez nessa condição, trabalhar melhor e analisar melhor a avaliação de desempenho. A avaliação de desempenho você olha, tá bom, ah, não está bom, entendeu, e fica por isso mesmo. Então, você vai avaliar só você sozinha, então, tinha que ser uma coisa institucional. Você tem que institucionalizar a avaliação de desempenho, entendeu, para todos os setores. Não adianta eu querer só fazer no meu setor entendeu, que aí do lado não faz, aí, o funcionário sempre, você sabe, olhando para o lado, para o rabinho no outro [...]. (CH-6)

Ainda em relação à UFES, as chefias imediatas afirmam que é necessário haver um retorno da instituição após a avaliação de desempenho e, assim como os TAE, sentem que existe uma falta de interesse da UFES em promover melhorias nas condições de trabalho após a avaliação de desempenho. Essa situação pode ser constatada na seguinte argumentação:

É isso que eu te falo, por exemplo, você avalia os equipamentos, né, você pode até apontar, mas eu nunca vi alguém depois, depois da avaliação de desempenho vai para o setor de recursos humanos e chegou aqui e falou assim: nossa, realmente vocês estão precisando de equipamentos, entendeu? E às vezes você coloca lá que está faltando, mas ninguém te procura para falar. Alguém ler aquilo, tabular aquilo e ver aquilo [...]. (CH-6)

Como já destacado nas categorias dos TAE, podemos inferir que a melhoria das condições de trabalho, quando realizada, tem por objetivo aumentar a produtividade do indivíduo, sem o verdadeiro retorno financeiro. Desse modo, observa-se que, na universidade estudada, poucas são as mudanças decorrentes da melhoria das condições de trabalho. Se não existe um aumento da chamada produtividade, conforme o objetivo da reforma gerencial, tampouco são oferecidas as condições necessárias ao trabalhador para este desempenhar suas funções no local onde permanece boa parte de sua vida.

\section{Os sistemas de progressão na universidade}

Como existe uma intenção que a avaliação de desempenho consiga controlar o trabalhador por meio de seus objetivos gerencialistas, quase todas as chefias imediatas questionaram o fato da avaliação de desempenho ser utilizada, atualmente, na instituição apenas como forma de progressão. Destaca-se abaixo a manifestação da chefia imediata quanto à progressão:

Não saberia te dizer assim, como isso depois é tabulado, né, mas eu acho que os pontos fortes dos servidores são levados em consideração para aquela questão da média, né, mas eu não sei como isto é utilizado depois. Não vejo, assim, uma resposta da avaliação de desempenho, a não ser aquele questionário que você consegue uma média para efeito de, vamos dizer, de progressão. O restante eu não vejo uma resposta tão clara. (CH-4)

Durante a análise das entrevistas, observou-se que as chefias imediatas defendem uma avaliação de desempenho e um programa de capacitação que não tenham efeitos somente para a progressão, mas que leve os TAE a buscar novos conhecimentos. Verifica-se, assim, uma dúvida por parte das chefias imediatas, quanto a exigir a aplicação das novas formas de dominação impostas pela legislação atual ou confrontar-se com os TAE que demonstram ter interesse somente na progressão.

Ressalta-se que a exigência pela capacitação não advém somente das chefias imediatas. Estas são as primeiras pessoas a ter contato com a administração da universidade, que é responsável por distribuir as normativas de acordo com o que é estipulado na legislação. Assim, em termos da avaliação de desempenho, essas normas estão cada vez mais ligadas ao modelo proposto na reforma gerencial, que defende uma eficiência no serviço público a ser atingida com os programas de capacitação e as políticas de mérito para os servidores públicos. 
Ainda em relação à capacitação, Leal e Schmitt (2002) afirmam que a busca contínua por conhecimentos é uma das principais exigências das organizações. Por isso, as chefias imediatas da UFES destacam esse quesito, ou seja, acredita-se que os trabalhadores nunca estão sendo utilizados de acordo com seu potencial. No entanto, o aumento do conhecimento por meio da capacitação não necessariamente torna os indivíduos mais críticos.

Assim, para as chefias imediatas, os TAE devem compreender que seu papel dentro do serviço público é peça fundamental para o crescimento da universidade. Ou, como afirmam Pagès, Bonetti, Gaulejac et al. (2008), o indivíduo deve tornar-se uma engrenagem, investindo tudo na organização para fazê-la funcionar. Faria e Meneghetti (2007a) acrescentam que, ao considerar o trabalhador uma engrenagem do sistema, a organização enxerga o sujeito de forma passiva e não como um indivíduo consciente e capaz de modificar seu trabalho. De forma acrítica, as chefias imediatas ressaltam a importância dos TAE para a universidade:

Eu te falo porque, com 35 anos de serviço, eu já passei por todas as fases possíveis que você possa imaginar. Fases ruins, que a gente recebia salários ruins, aí todo mundo reclamava porque o salário era ruim, você não tinha nada. Aí, veio o salário ainda não está bom, mas deu uma boa melhorada, você fazia um curso de especialização e não servia de nada, eu fiz dois e na época não serviu de nada, fiz porque eu queria me capacitar. Hoje em dia, não, todo mundo pode estudar que melhora, você faz uma especialização que melhora, você faz um mestrado que melhora, mas não está mudando o desempenho do servidor. Então, o que falta é trabalhar, engajar o servidor, mostrar para ele, que ele é uma peça importante dentro desta engrenagem que é o serviço público, entendeu? Então, atualmente, eu estou muito cética dentro desse negócio. (CH-6)

Ainda em relação à progressão, as chefias imediatas destacaram que a questão do desempenho é vista de forma diferenciada, conforme o tempo do servidor na instituição. Ou seja, quanto menor o tempo de instituição, maior é a aceitação da avaliação de desempenho, como ilustra esta fala:

O pessoal mais antigo, eles têm certa dificuldade na compreensão, porque é uma coisa moderna, né, que chegou há pouco tempo, mas o pessoal mais novo, que entrou agora recente, quando entra na universidade ele já tem um parâmetro de como funciona o serviço público, então, facilita para ele essa avaliação, apesar dos mais antigos terem mais experiência, mas eles demoraram muito para interagir com essa atividade que os RH estão colocando [...]. (CH-10)

Para Pagès, Bonetti, Gaulejac et al. (2008), os trabalhadores com menos tempo de instituição são mais alienados que seus antecessores, assim como mais enquadrados e integrados, já que estes, ao ser admitidos, são pegos por um sistema que os abraça de todos os lados, tornando-os de "corpo e alma" para a organização.

Analisando as falas das chefias, é possível inferir que, aos poucos, a política de gestão de pessoas proposta pelo governo vem conseguindo atingir seus efeitos, havendo, portanto, uma maior canalização de energia para obter a progressão e, consequentemente, subir na carreira. Se a entrada de novos TAE estiver relacionada à mudança de desempenho decorrente da avaliação, os objetivos gerencialistas que regem a avalição de desempenho poderão ser alcançados, lembrando que há uma tendência na universidade de muitos servidores se aposentarem, como indica a seguinte fala:

[...] na universidade acaba ficando cada vez mais difícil agora, porque a gente está com um monte de gente aposentando, há dois meses atrás nós tivemos, aqui, só os colegas que aposentaram foram sete pessoas em um grupo só, então, quer dizer, nós aqui, o que que acontece, cada vez aumentando mais a quantidade de trabalho, diminuindo os funcionários, 
então, quer dizer, e se um não ajudar o outro como a gente vai dar conta do trabalho? $(\mathrm{CH}-$ 9)

Nota-se que cerca de 600 TAE têm no mínimo 30 anos de serviço na instituição, ou seja, estão próximos da aposentadoria. Assim, é provável que a política de gestão de pessoas utilizada na instituição modifique-se rapidamente, visto que os que não ocupam cargo em extinção serão substituídos por novos concursados. Desse modo, a adaptação às novas políticas gerenciais pode atingir mais servidores, já que, como enfatizam Pagès, Bonetti, Gaulejac et al. (2008), a dominação torna-se mais ou menos forte de acordo com a característica de cada grupo. Além disso, os trabalhadores novos tendem a aceitar as regras organizacionais sem fazer questionamentos quanto à sua legitimidade e validade (FARIA e MENEGHETTI, 2007c).

\section{Considerações Finais}

Este estudo buscou compreender, a partir do entendimento dos servidores técnico-administrativos em educação das classes C, D e E e das chefias imediatas, como ocorre a avaliação de desempenho na UFES. Ao comparar o entendimento dos TAE e das chefias imediatas sobre a avaliação de desempenho, pode-se observar algumas convergências, mas, também, argumentos contraditórios quando comparadas as falas desses entrevistados.

Uma das divergências observadas relaciona-se à maneira como é realizada a avaliação. As chefias imediatas dizem ter dificuldade para realizar a avaliação de desempenho de modo objetivo, como é requerido na legislação, no entanto, esses entrevistados afirmam que buscam maneiras para que avaliação seja justa. Já os TAE apontam que a subjetividade na avaliação pelas chefias imediatas favorece alguns servidores.

O medo de que a avaliação resulte em represálias e penalizações faz com que os TAE tenham receio na hora de fazer avaliação, assim como para as chefias imediatas existe um receio de que a avaliação possa criar um conflito com o avaliado. Além disso, nota-se que a chefia imediata busca na avaliação de desempenho um instrumento que possa trazer melhores resultados, enquanto que os TAE têm a esperança que esta promova melhores condições de trabalho.

Apesar dos problemas apresentados, as chefias imediatas e os TAE aprovam a utilização da avaliação de desempenho. Assim, os entrevistados acreditam que esse instrumento é necessário para promover melhorias no serviço público. Para tanto, os entrevistados apontaram que é necessário um maior retorno por parte da universidade após a realização da avaliação de desempenho.

Outras contradições foram observadas a partir da análise dos documentos que abordam a avaliação de desempenho e da categorização das falas dos TAE e das chefias imediatas. A primeira relaciona-se à maneira que a avaliação de desempenho é prescrita em leis, decretos e resoluções e como esta é vivenciada na instituição. Existe uma legislação fundamentalmente gerencialista, que estipula uma avaliação de desempenho vinculada às metas institucionais. Entretanto, em termos práticos, as notas da avaliação são frutos de critérios subjetivos, como apontado nas falas dos TAE.

Outro aspecto contraditório diz respeito à defesa pela manutenção da avaliação de desempenho. No entender dos TAE e das chefias imediatas, ela vem sendo utilizada na universidade especialmente por questões salariais. Ou seja, além da progressão por mérito, outros resultados não são visíveis. No entanto, tanto os TAE como as chefias imediatas acreditam que a avaliação pode proporcionar maiores contribuições para a universidade e para os trabalhadores. Assim, os sujeitos entrevistados defendem sua continuidade na administração pública. Nesse sentido, existe um total alinhamento entre os desejos dos TAE e das chefias imediatas em relação ao proposto na reforma gerencial e uma falta de reflexão crítica sobre os objetivos ocultos da avaliação de desempenho. 
Também foi possível perceber que a avaliação de desempenho foi colocada como panaceia para os problemas que giram em torno da qualidade do serviço público e da motivação e desenvolvimento do trabalhador. Assim, entre uma legislação essencialmente funcionalista e uma gestão que se confronta entre o gerencialismo e o patrimonialismo, vemos uma expectativa de melhores resultados por parte das chefias imediatas e uma autopersuasão por parte dos TAE, sendo que estes últimos se satisfazem diante do valor pecuniário que lhes é ofertado.

Ao ter sua progressão satisfeita, os TAE esquecem as outras necessidades, aceitando continuar com as condições de trabalho que não são satisfatórias e exercendo funções para as quais não sentem que possuem aptidões. Assim, a avaliação de desempenho funciona como um processo de mediação, visto que ao conseguir a mudança de nível o servidor idealiza o plano de carreira como uma grande conquista. Nota-se, também, que os TAE não têm consciência da finalidade da avaliação de desempenho, por isso, superestimam a capacidade de mudanças que podem advir do emprego desse instrumento se implementado na universidade como defende a lógica gerencialista.

Ainda quando verificamos de forma mais minuciosa as leis que regem a avaliação de desempenho, percebemos que existe uma intenção de controle e de busca por resultados tal como nas práticas de gestão de pessoas visualizadas por Pagès, Bonetti, Gaulejac et al. (2008) em seus estudos.

Desse modo, a avaliação de desempenho utilizada na universidade se afasta ao mesmo tempo que se aproxima da organização estudada por Pagès, Bonetti, Gaulejac et al. (2008). Afasta-se no sentido de não existirem metas plenamente definidas entre a instituição e os TAE, embora em termos de leis e resoluções estas estejam descritas. Aproxima-se quando é estabelecido um plano de carreira para ascensão condicionada ao mérito, embora na universidade estudada esse mérito possa ser fictício.

Outras semelhanças com os estudos de Pagès, Bonetti, Gaulejac et al. (2008) também podem ser destacadas, como a ambição dos TAE em relação ao aumento salarial, a autopersuasão ao defender a avaliação de desempenho mesmo não tendo melhorias efetivas das condições de trabalho e a individuação no que se refere à preocupação somente com o próprio crescimento na carreira. Destaca-se, também, a busca por uma avaliação objetiva, ou seja, considerada científica, pelos servidores.

Reconhece-se, aqui, a necessidade da sociedade receber um atendimento de qualidade, principalmente quando se trata de uma instituição pública voltada à Educação Superior. No entanto, acredita-se que as técnicas gerenciais são implementadas sem o real questionamento de sua contribuição para os trabalhadores e para a sociedade. Nesse sentido, este estudo buscou demonstrar que as respostas advindas dos números são limitadas e devem ser questionadas. E mesmo que os dados utilizados na avaliação de desempenho fossem tabulados e divulgados pela universidade, crítica de muitos entrevistados, eles seriam insuficientes para demonstrar a realidade da UFES, visto que não é possível captar e expressar a realidade dos servidores somente por meio da quantificação de alguns aspectos.

Ressalta-se que este artigo não buscou obter uma resposta para os problemas da avaliação de desempenho da UFES, mas compreender de forma crítica o entendimento dos servidores técnico-administrativos em educação e das chefias imediatas como ocorre a avaliação de desempenho na instituição. Sabe-se da limitação desta pesquisa ao se restringir-se a apenas uma universidade entre as várias IFES existentes no Brasil, assim como dos inúmeros órgãos que hoje compõem a administração pública. Entretanto, esta investigação constitui um incentivo para um questionamento maior, uma reflexão sobre como o gerencialismo invadiu a administração pública, por meio de leis, decretos e resoluções, e tornou a melhoria do serviço público refém de dados quantitativos questionáveis. Se, por um lado, torna-se difícil lutar contra os modelos e instrumentos capitalistas utilizados na administração pública dos países ocidentais, por outro, somente com uma crítica contundente será possível alcançar algum resultado que possa trazer melhorias efetivas para os servidores e, ao mesmo tempo, proporcionar um serviço público adequado aos seus usuários.

Desse modo, a reflexão aqui proposta tornou-se uma alternativa para construir uma realidade diferente nas organizações públicas, que não fique à mercê dos impositivos criados pelas organizações capitalistas. 
Portanto, espera-se o desenvolvimento de novos estudos que envolvam o uso das técnicas gerenciais nas organizações públicas, não se esgotando este debate por aqui.

\section{Referências}

ABRUCIO, F. L. Trajetória recente da gestão pública brasileira: um balanço crítico e a renovação da agenda de reformas. Rev. Adm. Pública, v. 41, n. edição especial, p. 67-86, 2007.

BARDIN, L. Análise de conteúdo. Lisboa: Ed. 70, 2006.

BRASIL. Plano Diretor da Reforma do Aparelho do Estado. Brasília, DF: Ministério da Administração Federal e da Reforma do Estado, 1995.

BRASIL. Relatório final da Conferência Nacional de Recursos Humanos da Administração Pública Federal 2009. A democratização das relações de trabalho: um novo olhar sobre a política de gestão de pessoas da Administração Pública Federal. Brasília, DF: Ministério do Planejamento, Orçamento e Gestão, 2009.

BRESSER-PEREIRA, L. C. Gestão do setor público: estratégia e estrutura para um novo Estado. In: BRESSERPEREIRA, L. C; SPINK, P. (Orgs.). Reforma do Estado e administração pública gerencial. Rio de Janeiro: Ed. FGV, 1999. 21-38 p.

CARDOSO, F. H. Apresentação. In: BRASIL. Plano Diretor da Reforma do Aparelho do Estado. Brasília, DF: Presidência da República, 1995.

DESLANDES, S. F. O projeto de pesquisa como exercício científico e artesanato intelectual. In: MINAYO, M. C. S. (Org.). Pesquisa social: teoria, método e criatividade. 19. ed. Petrópolis, RJ: Vozes, 2007. 43-49 p.

DUTRA, A. Elaboração de um sistema de avaliação de desempenho dos recursos humanos da Secretaria de Estado da Administração - SEA à luz da metodologia multicritério de apoio à decisão. 1998. 443 f. Dissertação (Mestrado em Engenharia de Produção) - Programa de Pós-Graduação em Engenharia de Produção, Universidade Federal de Santa Catarina, Florianópolis, 1998.

FARIA, J. H. Economia política do poder: uma crítica da teoria geral da administração. v. 2. Curitiba: Juruá, 2004.

FARIA, J. H. (Org.). Análise crítica das teorias e práticas organizacionais. São Paulo: Atlas, 2007.

FARIA, J. H.; MENEGHETTI, F. K. A instituição da violência nas relações de trabalho. In: FARIA, J. H. (Org.). Análise crítica das teorias e práticas organizacionais. São Paulo: Atlas, 2007a. 278-298 p.

FARIA, J. H.; MENEGHETTI, F. K. As organizações e a sociedade unidimensional. In: FARIA, J. H. (Org.). Análise crítica das teorias e práticas organizacionais. São Paulo: Atlas, 2007b. 8-28 p.

FARIA, J. H.; MENEGHETTI, F. K. O Sequestro da subjetividade. In: FARIA, J. H. (Org.). Análise crítica das teorias e práticas organizacionais. São Paulo: Atlas, 2007c. 45-67 p.

FARIA, J. H.; SCHMITT, E. C.; MENEGHETTI, F. K. O imaginário vigiado nas relações de trabalho. In: FARIA, J. H. (Org.). Análise crítica das teorias e práticas organizacionais. São Paulo: Atlas, 2007. 68-91 p.

GIL, A. C. Gestão de pessoas: enfoque nos papéis profissionais. São Paulo: Atlas, 2001.

GOMES, D. C.; BARBOSA E SILVA, L.; SÓRIA, S. Condições e relações de trabalho no serviço público: o caso do governo Lula. Revista de Sociologia Política, v. 20, n. 42, p. 167-181, 2012. 
LEAL, A. P.; SCHMITT, E. C. Recursos humanos e a prática ideológica: estudo de caso em uma organização multinacional. In: ENCONTRO NACIONAL DE PÓS-GRADUAÇÃO E PESQUISA EM ADMINISTRAÇÃO, 26., 2002, Salvador. Anais... Salvador: EnANPAD, 2002. 1-15 p.

NASCIMENTO, C. M. D. V.; BERNARDIM, L. M. Avaliação de desempenho nos bancos públicos. Revista Eletrônica Lato Sensu, p. 1-17, 2007.

NOVELLI, J. M. N. Estado, administração e burocracia pública: o caso do Governo Lula (2003-2009). In: ENCONTRO DA ASSOCIAÇÃO BRASILEIRA DE CIÊNCIA POLÍTICA, 7., 2010. Recife. Anais... Recife: Encontro ABCP, 2010, p. $1-20$.

PAGÈS, M. et al. O poder das organizações. São Paulo: Atlas, 2008.

PAULA, A. P. P. Administração pública brasileira entre o gerencialismo e a gestão social. Revista de Administração de Empresas, v. 45, n. 1, p. 36-49, 2005a.

PAULA, A. P. P. Por uma nova gestão pública: limites e potencialidades da experiência contemporânea. Rio de Janeiro: Ed. FGV, 2005b.

PEREIRA, M. F.; MARQUES, S. M. A importância da qualificação e capacitação continuada dos funcionários: o caso da Universidade Federal de Juiz de Fora. In: ENCONTRO NACIONAL DE PÓS-GRADUAÇÃO E PESQUISA EM ADMINISTRAÇÃO, 28., 2004, Curitiba. Anais... Curitiba: EnANPAD, 2004. 1-15 p.

PHILADELPHO, P. B. G.; MACÊDO, K. B. Avaliação de desempenho como um instrumento de poder na gestão de pessoas. Aletheia: Revista de Psicologia da Ulbra, n. 26, p. 27-40, 2007.

QUEIROZ, A. A. Perfil, propostas e perspectivas do governo Dilma. Brasília, DF: DIAP, 2011.

SANTOS FILHO, N. G. et al. Mudança organizacional no Legislativo brasileiro: discutindo as possibilidades de aplicação do institucionalismo sociológico na análise da modernização da estrutura administrativa da Câmara dos Deputados. In: ENCONTRO DE ADMINISTRAÇÃO PÚBLICA E GOVERNANÇA DA ANPAD, 4., 2010, Vitória. Anais... Vitória: EnAPG, 2010, p. 1-17.

SILVA, M. L. R. Uma leitura psicanalítica da ferramenta gerencial da avaliação de desempenho. 2010.77 f. Dissertação (Mestrado em Psicologia) - Programa de Pós-Graduação em Psicologia, Pontifícia Universidade Católica de Minas Gerais, Belo Horizonte, 2010.

SIQUEIRA, M. V. S.; MENDES, A. M. Gestão de pessoas no setor público e a reprodução do discurso do setor privado. Revista do Serviço Público, v. 60, n. 3, p. 241-250, 2009.

TRAGTENBERG, M. Administração, poder e ideologia. São Paulo: Cortez, 1989.

TRIVIÑOS, A. N. S. A pesquisa qualitativa em educação. São Paulo: Atlas, 1987.

UNIVERSIDADE FEDERAL DO ESPÍRITO SANTO. Perguntas frequentes: Avaliação de desempenho. Disponível em: 〈http://www.progepaes.UFES.br/avaliacao-de-desempenho/perguntas-frequentes >. Acesso em: 13 abr. $2013 \mathrm{a}$.

UNIVERSIDADE FEDERAL DO ESPÍRITO SANTO. Quadro dos servidores da Universidade. Disponível em: <http://www.progepaes.UFES.br/quadros-e-informacoes>. Acesso em: 14 abr. $2013 \mathrm{~b}$. 